\title{
POSITIONING ARCHITECTURE IN CULTURE
}

\author{
Ashadi Ashadi \\ Department of Architecture, Universitas Muhammadiyah Jakarta, INDONESIA \\ Email: ashadi@ftumj.ac.id
}

\begin{abstract}
Architecture could be defined as the relation of form-function-meaning in a cultural framework. This paper aimed to understand the position of architecture in culture. The method used was correlation and interpretation. Correlation method connected architectural forms with cultural forms, while interpretation method provided an interpretation of the relationship between the two, and the position of architecture in culture. The results showed that architecture as part of culture had almost the same form between the two. Architectural term included forms, functions, meanings, and ideas, while cultural term included physical culture, behavior patterns or social, value, and ideas systems. The architectural form became part of the physical form of culture, the architectural function became part of the form of social cultural system, the architectural meaning became part of the cultural value system, and the architectural ideas became part of the cultural ideas systems.
\end{abstract}

Keywords: Architecture; culture; form; function; meaning.

\section{INTRODUCTION}

Koentjaraningrat described the cultural form as a cosmic circle (Koentjaraningrat, 1996). The first circle which was outermost was physical culture. The second circle located inside and smaller than the first circle was the behavior system. The third circle which was in the deepest was the ideas system. Artifacts included all objects of the work of human supporters of culture, which were concrete, touchable and visible. Behavior system included all human behavior that supported culture based on the system (social system) and were concrete (visible). The ideas system included ideas that emerge from the minds of each individual human being supporting culture, and were not concrete (abstract), could not be touched (untouchable) and could not be seen (invisible). (Figure 1).

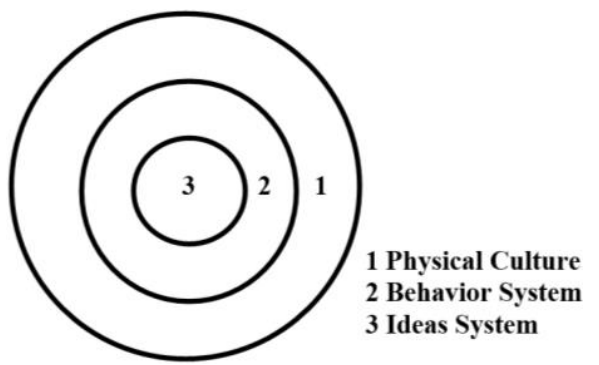

Figure 1. Diagram of the cultural form (three aspects) according to Koentjaraningrat (Source: author, illustration based on Koentjaraningrat).

Koentjaraningrat added, an example of a concrete form of culture, which in the diagram depicted as circle 1, the largest, was among other magnificent buildings such as the Borobudur temple, movable objects such as tank ships, computers, plates, glass, buttons clothes, and so on. All objects of human work were concrete and could be touched and photographed. Specific designation for culture in this concrete form was physical culture. Circle 2 illustrated the form of human behavior, for example dancing, talking, behavior in doing a job, and others. Culture in this form was still concrete, could be photographed and filmed. All movements carried out from time to time and from day to day, were patterns of behavior based on the system. So, patterns of human behavior were called social systems. Circle 3 illustrated the form of culture ideas; its place was in the head of each individual citizen of the culture concerned, which he carried wherever he went. Culture in this form was abstract, could not be photographed and filmed, and could only be known and understood by members of that culture after it had been studied in depth, either through intensive interviews or by reading. Culture in the form of ideas was also patterned and based on certain systems called cultural systems. Koentjaraningrat, implicitly, put architecture in the first circle, namely as physical culture. He considered architecture a physical object of culture. This view was certainly not right.

This paper tried to place the position of architecture in culture based on the conception of architecture itself. The method used was correlation and interpretation. Correlation method connected architectural forms with cultural forms, while interpretation method provided an interpretation of the relationship between the architectural forms and cultural forms, and the position of architecture in culture based on 
their forms. The methods consisted of the following three steps. The first step, built an architectural concepts by paying attention to some architectural conceptions; Here including dialogued the concept of western architecture with eastern architecture, because scientists generally distinguished it. The second step, dialogued the architectural concept into the Koentjaraningrat's cultural concept. And the third step, interpreted the results of the dialogue.

\section{ARCHITECTURE AND CULTURE}

Etymologically, architecture came from the Latin word 'architectura' and from the Greek 'arkhitekton' (arkhi = head and tekton = builder), which meant the head builder. Architecture actually had a much broader scope than just being a chief builder. The scope of conceptions of architecture varied greatly, and each interpretation that was raised would be greatly influenced by the background of one's thinking about the world around him and the experiences he had gone through. Louis Isadore Kahn (1901-1974), a modern architectural theorist, once said as quoted by Cornelis van de Ven in Space in Architecture, essentially, architecture was space created in a way that was actually planned (van de Ven, 1991). Many prominent architects in the twentieth century made statements that for architecture, the most fundamental was space. Since the 1970s, understandings of space conceptions involving cultural dimensions were born. Amos Rapoport in the Human Aspects of Urban Form, explained, space was not just dealing with three-dimensional physical space, because at different times and contexts, a person was actually dealing with a different kind of space. People from different cultures would differ in how they divided their world, gave value to its parts, and measured it. Space was the translation of the world around us in three dimensions, namely the translation of intervals, relationships and distances between humans and humans, humans and things, things and things. Rapoport added, actually planning and design at all scales, ranging from a very large area to the arrangement of home furniture, could be considered as a space arrangement for various uses, according to the provisions that reflect the needs, values, and desires of groups or individuals who made these arrangements. The spatial arrangement itself expressed meaning and had communicative characteristics. (Rapoport, 1977).

At first, humans behaved and acted on the instinctual urge to meet their biological needs. In the next life process, humans behaved and acted based on their culture. Culture that contained values, norms, and beliefs were used by humans to understand the phenomena that existed in their environment, then sorted them out or group them in good and bad categories to plan steps and choosed attitude or action in accordance with the capabilities they had. Because every activity that fulfilled those needs always required space to carry out these activities, then every activity that fulfilled needs was also always carried out in spaces that had been classified and selected for the relevant activities (Suparlan, 1996).

According to Josef Prijotomo (1988), the important thing that culture where architecture existed, applied in a certain space and time, that was when architecture was the cultural peak that had been determined by the supporting society. Architecture was a logical consequence of that culture; architecture was the fruit that was raised by the cultural tree. Culture was the foreground for architecture (Prijotomo, 1988).

\section{Architecture: Relation of Form-Function- Meaning}

In architectural studies, the relation of formfunction-meaning was one of the important themes. It was started by Marcus Vitruvius Pollio (around the first century BC), who stated that all buildings had to be built with reference to: durability (firmitatis), convenience (utilitatis), and beauty (venustatis) (Morgan, 1914) (Figure 2).

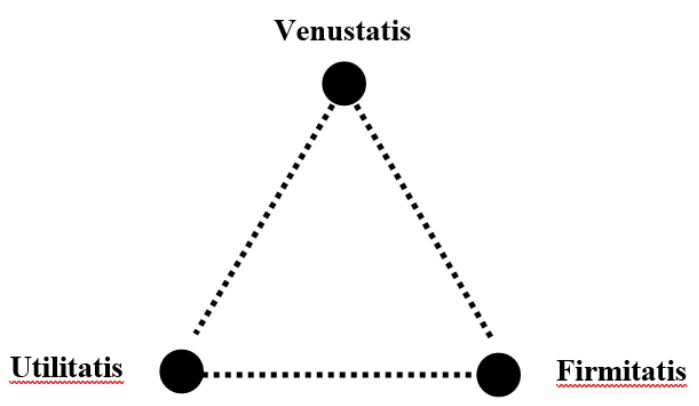

Figure 2. Diagram of three aspects in architecture according to Vitruvius (Source: author, illustration based on Vitruvius in Morgan).

The Vitruvius concept was then tested by David Smith Capon. Capon concluded, there were six categories in the principles of architecture (principles of good architecture), which were grouped into primary and secondary categories, namely: function, form, meaning as primary categories, and context, construction, spirit as secondary categories (Capon, 1999) (Figure 3).

Purnama Salura \& Bachtiar Fauzy developed the concept of the form-function-meaning rotation. Every architectural design product had to give priority 
to the elements of form-function-meaning. These three elements formed a triangle figure, which was always in a state of change (spinning) (Salura, \& Fauzy, 2012) (Figure 4).

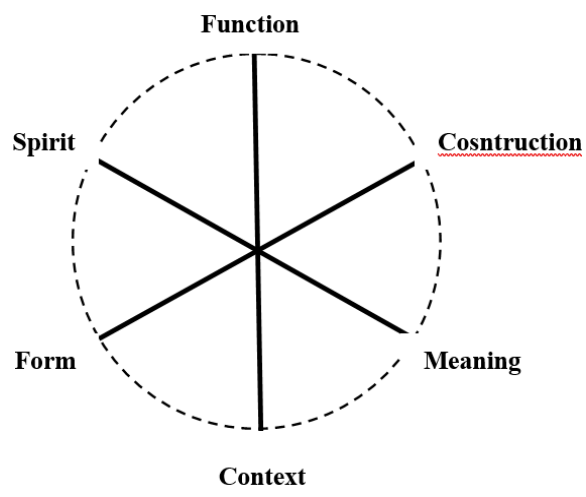

Figure 3. Diagram of six aspects in architecture according to Capon (Source: author, illustration based on Capon).

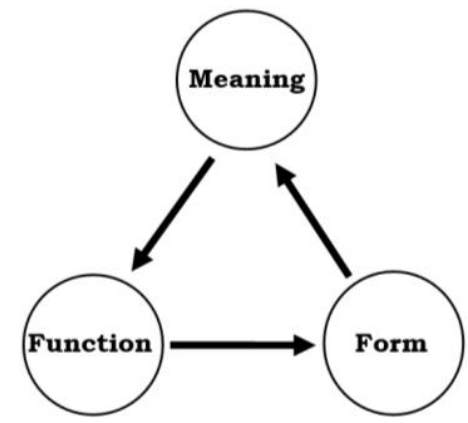

Figure 4. Diagram of relation of three aspects in architecture according to Salura \& Fauzy (Source: author, illustration based on Salura \& Fauzy).

Meanwhile, according to Mangunwijaya, architecture consisted of two categories namely Guna and Citra. Guna dealed with uses and benefits, and Citra dealed with symbols. (Mangunwijaya, 1995). This differed from many views on architecture, especially architecture from a Western perspective. (Figure 5).

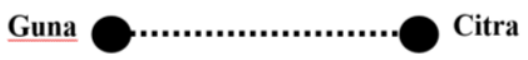

Figure 5. Diagram of two aspects in architecture according to Mangunwijaya (Source: author, illustration based on Mangunwijaya).

In modern architecture, led by Sullivan, used a reductionist approach in viewing architecture. The bombastic slogan "form follows function" became the basis for designing modern architecture. The assumption was that architecture, as something deliberately created, was purely functional manifestation. According to this understanding, the function was defined as an activity carried out by humans in the container form of architectural buildings. In architectural design had to pay attention to activities that would be contained in the building. (Leupen, 1997; Roth, 2014). The function of this understanding was to prioritize efficiency, and paid less attention to the underlying values and meaning.

Postmodernism defined the architectural functions was the role and ability of architecture to influence and served humans, not only humans who worked in activities, but also people who thought, had feelings and emotions, had dreams and ambitions, had nostalgia and memory. Rob Krier stated that architecture (form of space) had to provide physical protection from environmental influences, created a framework for activities, above all, architecture had to express symbolic and ethical values. (Krier, 2001).

The meaning of architecture was the result of the interpretation of the relationship between form and function in a cultural framework. Basically the architectural form was neutral, meaningless, because the architectural form was the architectural form itself; it was somewhere yes indeed the place was there. Only someone (subject) who then gave meaning to the architectural form. An architectural form (object) could be said to be meaningful because of the wisdom of a person (subject) who paid attention to that architectural form. The meaning was given by someone as a subject to the form of architecture as an object, in accordance with the perspective of the subject.

\section{Aspects of Form, Function, and Meaning in Culture}

On another place, Koentjaraningrat divided the cultural form into four, namely, first, the outermost circle, the set of elements of physical culture; second, the circle within it, the social system; third, the circle within it, the idea system of culture; and fourth, the deepest circle, cultural values (Koentjaraningrat, 1996). (Figure 6).

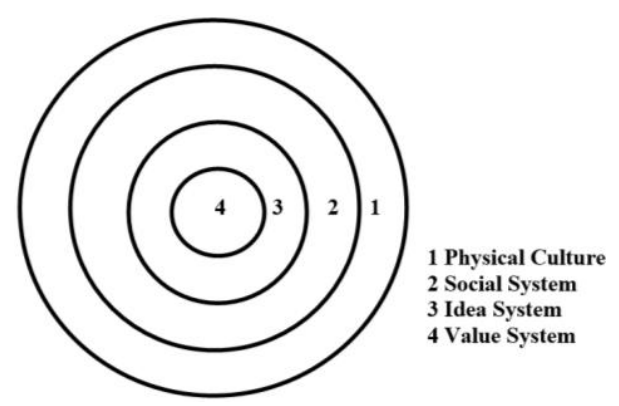

Figure 6. Diagram of the cultural form (four aspects) according to Koentjaraningrat (Source: author, illustration based on Koentjaraningrat). 
Cultural values were the conceptions that lived in the minds of most of the people about things they considered very noble. The existing value system in a society was used as an orientation and reference in behaving and acting, both in personal life and in society. (Koentjaraningrat, 1996). People supporting a culture used cultural values to select what they felt, was the most appropriate or best to encourage meaningful interpretations of and about the situations and phenomena they faced in their environment, through the institutions and customs that applied, in order to meet the needs of their lives. (Suparlan, 1995). Culture at the first level was a tool or instrument that appeared in the framework of fulfilling human psycho-biological needs. In order to fulfill the individual's psycho-biological needs and maintain the social group's life, the minimum conditions had to be met by the individual members of the social group. The minimum conditions consisted of seven basic needs, namely nutrition (metabolism), reproduction, bodily comfort, safety, relaxation, movement, and growth. (Malinowski, 1988). Culture could be defined as a guideline for the life of a society, consisting of sets of reference systems or cognitive models that applied at various levels of feeling and awareness, which were used selectively to encourage the realization of meaningful interpretations and regarding the situations and symptoms they faced in order to fulfill their life needs both as individuals and as members of society (Spradley, 1997). Every activity that fulfilled the needs of human life, both as individuals and as members of the community, required space to carry out these activities. So that every activity fulfilling the necessities of life was carried out in spaces that had been classified and selected to accommodate these activities. (Suparlan, 1996).

The concept of culture, according to Clifford Geertz, meant a pattern of historically transmitted meanings manifested in symbols, a system of inherited concepts expressed in symbolic forms through which humans communicated, preserved, and developed their knowledge of life and attitudes towards life (Geertz, 1973). Basically all cultural phenomena could be understood through three aspects: form, function, and meaning. Every cultural phenomenon had a function, then the function had its own form, which in turn would give a certain meaning. The relationship factor between these three aspects made a different meaning. With the same function and form, but displayed in a different relationship process, the resulting meaning would be different (Ratna, 2010). The analysis model involving these three aspects was adopted through the opinion of Ralph Linton, who stated that each cultural phenomenon consisted of four elements, namely form, meaning, benefit, and function (Linton, 1936). The elements of benefits and functions could be combined into functional elements, because they were almost the same. (Figure 7).

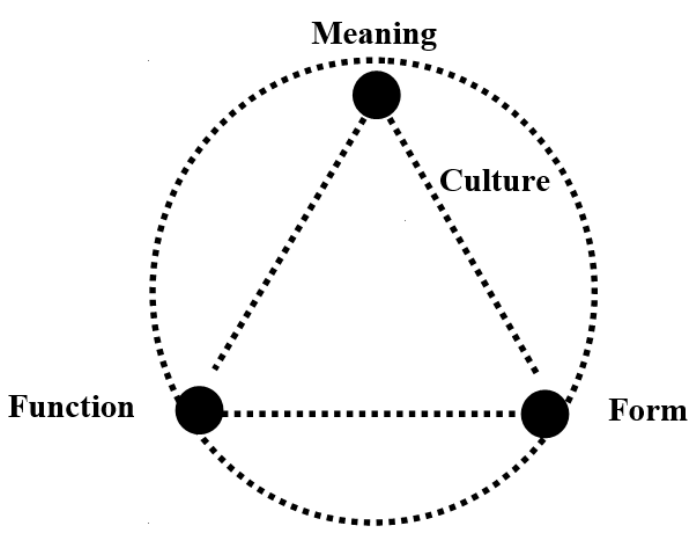

Figure 7. Diagram of three aspects: form, function, and meaning in culture

According to van Peursen, culture was a way for humans to express themselves, by looking for the right relations to the world around them. Culture was a strategy to channel these relations optimally (van Peursen, 1988). Thus, aspects of that culture would always be related to one another. Amos Rapoport gave a question: "what is the purpose of architecture?" The goal was more than just a shelter function. Architecture could provided an expression for certain activities; stated status, or personal matters; displayed and supported cosmological beliefs; submitted information; helped establish personal or group identity; and invoked value systems. If shelter was the only architectural function, or even the principal, then there would be little variation in the form to be found. Even though architecture had produced a variety of buildings with different objectives, ranging from the combined living and worked to the separation of residence and work, starting from homes and workshops that were merged until the separation of the two and then up to the dedicated workplace and workshop, etc. Likewise, it could expect a tendency to use materials from the ease of obtaining these materials, which apparently had meaning and communicative functions. (Rapoport, 1984). From Rapoport's explanation, it could be seen that the function of architecture was closely related to architectural form and architectural meaning. Various architectural functions would produce diverse forms of architecture. These forms allowed the use of building materials that were varied and had a communicative meaning and function for the human user. 


\section{Positioning Form, Function, Meaning, and Idea of Architecture in the Culture}

In this paper, to see architecture from an Eastern perspective, the Mangunwijaya's theory is proposed. The concept of Guna in the Mangunwijaya's theory can cover two Vitruvius concepts: Firmitatis and Utilitatis, because the core of Guna is to obtain optimal utilization that is not limited to durability but also includes securing the life of the occupant or user (conveinance). Yet in reality there are times when the two aspects become one. Concept of Citra shows a "picture" (image), an impression of appreciation that captures meaning for someone and refers to the level of culture. Whereas Venustatis is intended as an aspect of beauty or can be compared with aesthetics. So that the Citra can be juxtaposed with Venustatis, even though the two are not the same meaning. Many experts distinguish the perspective of Western and Eastern architecture. Western architecture is very material and Eastern is very spiritual; Western architecture is concerned with building objects and procedures, while Eastern architecture looks more at social and spiritual processes and values. (Burhany, 2010; Istanto, 1999).

Citra of architecture can be understood not from its form, but from its space. This is stated as: "Expressive space", I.e. space, along with its boundaries and accessories; It is the gatra or volumes in accordance with cultured humans. From this statement, it can be underlined that appreciation of architecture means appreciation of space. And that gatra which in fact refers to the form of architecture. (Gunawan, 2009). Implicitly, Mangunwijaya associates Citra of architecture with space. In this paper, this space is included in the category of architectural forms. To be clear, at a certain level, Guna can be juxtaposed with function, whereas Citra, at a certain level, can be juxtaposed both with form and with meaning. (Figure 8).

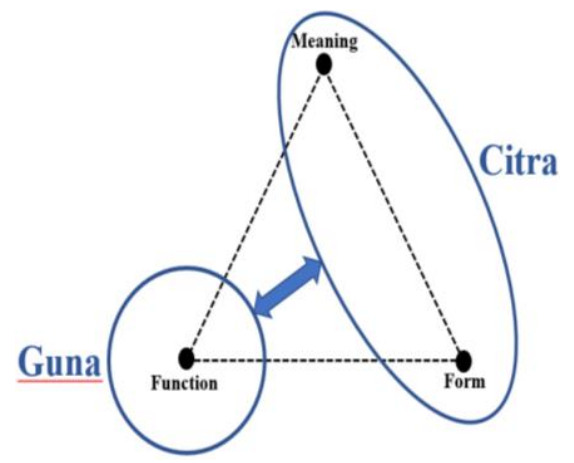

Figure 8. Diagram of position of guna-citra in the relation of form-function-meaning in architecture
The relation of form-function-meaning in architecture can be briefly described as follows. For example, a building with all its rooms and amenities, which in this study is called an architectural form, displays its expression and then together with the functions in it will give a message to the observer. The observer will process the message and give meaning based on the culture of the observer, and the culture behind the building.

Architecture as a result of a design certainly involves ideas. Without the involvement of new ideas in architectural design, the results of the architectural works can be categorized as copying results. Ideas are the driving force for the relation of form-functionmeaning aspects in architecture. The relation between form and function in architecture can explain the meaning of architecture. The relationship of functionmeaning in architecture will be able to explain the form of architecture. The relation of form-meaning in architecture will be able to explain the function of architecture. So that the three aspects are related to one another. Architectural ideas are ideas that drive these relationships. (Figure 9).

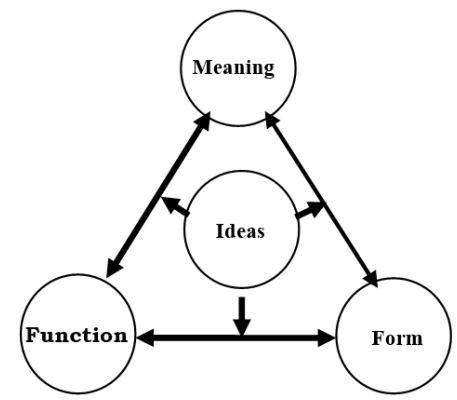

Figure 9. Diagram of relation of form-function-meaning in architecture; the idea of being a relationship mover

When integration between architectural concepts (four aspects, see figure 9) and cultural forms (three aspects, see figure 1), it will be seen: each aspect of architecture is part of each cultural form. The form of architecture is part of physical culture. Architectural functions are part of the behavior system. Architectural ideas are part of the ideas system. The meaning of architecture is values, which in the framework of the cultural form can be placed between social system (behavior pattern) and idea system. (Figur 10). When integration between the four aspects of architecture (see figure 9) with the four aspects of culture (see figure 6), it will be seen: architectural form is a part of physical culture (physical element), architectural function is a part of the social system (behavior pattern) of culture, architectural meaning is a part of cultural value system, and architectural idea is a part of cultural idea (Figure 11). 


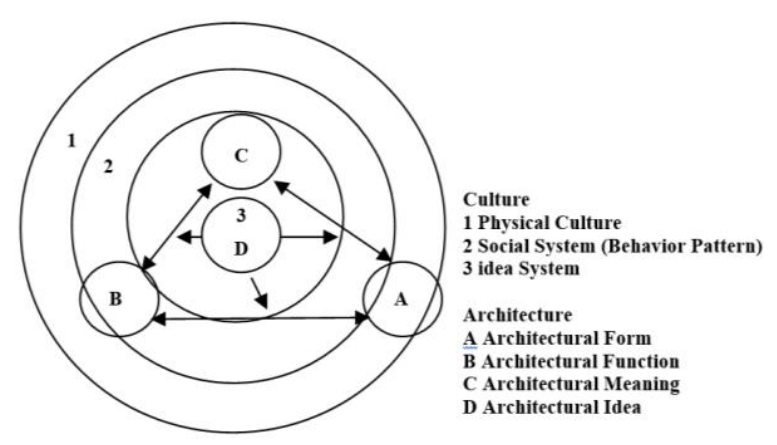

Figure 10. Diagram of positioning architecture (four aspects) in culture (three aspects)

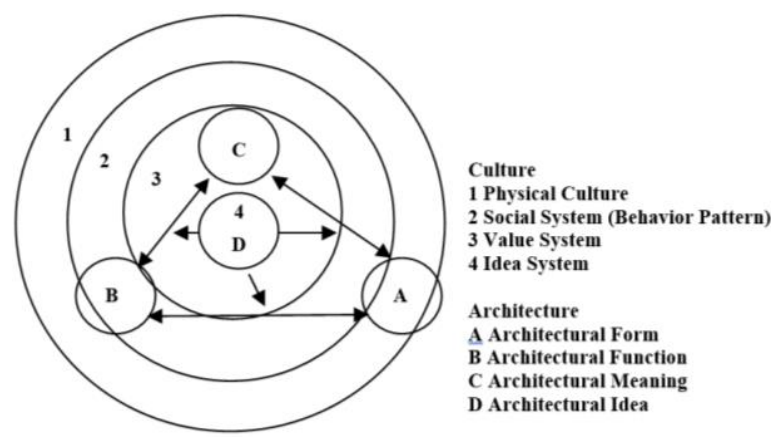

Figure 11. Diagram of positioning architecture (four aspects) in culture (four aspects)

Based on the four forms of culture above, architecture is physically including in the first circle group. However, on the other hand, architecture is a work of culture whose creation is through the processing of ideas and some of them contains cultural values and ideas, so that it belongs to the third and fourth circle group. Architecture in its design and creation also takes into account the behavior of the supporting community (social system), so that it could be includes in the second circle group. This shows that the images of the four forms of culture does not stand alone, they can even overlap with each other, and each can be described. Of course, each form of culture has different levels of ease in the description. Describing architecture as a physical culture is the easiest, while describing architecture as a system of ideas and values is the most difficult. For the latter, behind the physical form of architecture contains meaning. So to find out or uncover the meaning must be through symbols that are created and used by the supporting community.

\section{CONCLUSION}

Architecture can be defined: a relation of formfunction-meaning, and idea is the driving forces. Thus architecture has four important aspects, namely form, function, meaning, and idea. Meanwhile, culture, according to Kontjaraningrat, consists of four aspects, namely physical culture, social system, value system, and idea system. Architecture is part of culture. It places architecture not only as a physical culture, not only social system, not only value system, or not only ideas system, but architecture is included in all four aspects of that culture. The form of architecture becomes part of the physical culture, the function of architecture becomes part of the social system in culture, the meaning of architecture becomes part of the value system in culture, and the idea of architecture becomes part of the idea system in culture.

The architectural concept given in this paper is a new concept; it is needed for analysis and interpretation. This architectural concept makes it easier to read the comparison between architectural concepts and cultural concepts, between aspects of architecture and aspects of culture. Furthermore, this architectural concept can also be used to read and observe cultural phenomena around us.

\section{REFERENCES}

Burhany, N.R. (2010). Dalog Kritis Trilogi Vitruvius Vs. Dwilogi Mangunwijaya. Mektek, 10(1), 5561.

Capon, D.S. (1999). The Vitruvian Fallacy: Architectural Theory Volume One, John Willey \& Sons, New York.

Geertz, C. (1973). The Interpretation of Culture, Basic Books Inc., New York.

Gunawan, Y. (2009). Memahami Ruang Y.B. Mangunwijaya. Conference: National Seminar Jelajah Ruang Nusantara, di Surabaya

Istanto, F.H. (1999). Arsitektur "Guna dan Citra" Sang Romo Mangun. In Memoriam: Yusuf Bilyarta Mangunwijaya 6 Mei $1929-10$ Februari 1999. Dimensi Teknik Arsitektur, 27(2), 40-47.

Koentjaraningrat (1996). Pengantar Antropologi I, Rineka Cipta, Jakarta.

Krier, R. (2001). Komposisi Arsitektur, Erlangga, Jakarta.

Leupen, B. et al. (1997). Design and Analysis, van Nostrand Reinhold, New York.

Linton, Ralph (1936). The Study of Man: an Introduction, Appleton-Century, New York.

Malinowski, B. (1988). The Group and the Individual in Functional Abalysis. High Points in Anthropology, Alfred A. Knopf, New York.

Mangunwijaya, Y.B. (1995). Wastu Citra, Gramedia Pustaka Utama, Jakarta.

Morgan, M.H. (1914). Vitruvius: The Ten Books on Architecture, Harvard University Press, Cambridge. 
Prijotomo, J. (1988). Pasang Surut Arsitektur di Indonesia, Ardjun, Surabaya.

Van Peursen, C. A. (1988). Strategi Kebudayaan, Kanisius, Yogyakarta.

Rapoport, A. (1977). Human Aspects of Urban Form, Pergamon, Toronto.

----, (1984). Asal Mula Budaya Arsitektur. Pengantar Arsitektur, Erlangga, Jakarta

Ratna, N.K. (2010). Metodologi Penelitian Kajian Budaya dan Ilmu-Ilmu Sosial Humaniora Pada Umumnya, Pustaka Pelajar, Yogyakarta.
Roth, L.M., \& Clark, A.R. (2014). Understanding Architecture: Its Elements, History, and Meaning, $3^{\text {rd }}$ ed., Westview Press., Colorado.

Salura, P., \& Fauzi, B. (2012). The Ever-Rotating Aspects of Function-Form-Meaning in Architecture. Journal of Basic and Applied Scientific Research, 2(7), 7086-7090.

Suparlan, P. (1996). Antropologi Perkotaan. College Textbook, University of Indonesia.

---- (1995). Antropologi Dalam Pembangunan. College Textbook, University of Indonesia.

Van de Ven (1991). Ruang Dalam Arsitektur, Gramedia Pustaka Utama, Jakarta. 